\title{
Chieftaincy: An Anachronistic Institution within a Democratic Dispensation? The Case of a Traditional Political System in Ghana
}

\author{
Kwabena Boateng \\ (Corresponding Author) \\ Department of Social Sciences, Central University, Accra, Ghana \\ Email: sekyerehene2002@gmail.com \\ Stephen Afranie \\ Centre for Social Policy Studies, University of Ghana, Legon - Accra \\ Email: safranie@ug.edu.gh \\ DOI//http://dx.doi.org/10.4314/gjds.v17i1.2
}

\begin{abstract}
Prior to colonial rule, governance in Africa rested on chiefs. However, colonialism and other currents of social change reduced the powers and functions of chiefs. Critics tagged the chieftaincy institution as anachronistic and even predicted its demise during the struggle for independence. However, chieftaincy has persisted after several years of Ghana's independence. The paper specifically seeks to answer two fundamental questions: Is chieftaincy anachronistic? And, how relevant is chieftaincy in Ghana's democratic dispensation. The paper is a desk review examining the instrumentality of the chieftaincy institution in the midst of a web of reputational challenges in contemporary Ghana. The study unearthed that the anachronistic label is pivoted on the undemocratic nature of chieftaincy institution and, chieftaincy and land disputes. Despite the above label, it was also found that chiefs are instrumental in conflict resolution, governance and administration, promotion of education and economic empowerment and performance of representational and diplomatic roles. Though people continue to perceive the chieftaincy institution as undemocratic, the institution has critical roles to play in contemporary Ghana. This paper recommends that studies should be conducted on how chiefs can be integrated into modern governance structures for them to contribute to national development.
\end{abstract}

Keywords: Chieftaincy, Anachronistic, Democratic, Social change, Traditionalism, Conservatism 


\section{INTRODUCTION}

Chieftaincy originated years before Africa's encounter with European colonial administrators. The evolution of this institution was necessitated by the need for those engaged in sedentary lifestyle, to have individuals steer their affairs. It is interwoven in the social and cultural fabric of the land with the family head at the base of the traditional political hierarchy while the paramount chief is at its apex. In Ghana, paramount chiefs and kings are members of their respective Regional Houses of Chiefs (Brobbey, 2008; Brempong, 2007; Boafo-Arthur, 2006), duly constituted by the 1992 Republican Constitution. Chieftaincy connotes the system through which African traditional rule is conducted (Brobbey, 2008). The term includes queen mothers who are the female counterparts of chiefs, elected to and installed by those who select the chief. Under the paramount king/chief are the divisional chiefs, sub-chiefs and the village chiefs who are all accountable to the paramount chief through the hierarchy (Brobbey, 2008).

Prior to the advent of colonialism, chiefs performed significant functions (Brempong, 2007) that were geared towards safeguarding the survival and security of their subjects. During the era when intra and inter-ethnic conflicts were recurrent, chiefs were the commanders of their respective armies. The task of the chief and his council of elders included devising strategies to protect their subjects from both internal and external aggressors. Other functions included being intermediaries between the living and the dead, custodians of natural resources (Nukunya, 2016; Seini, 2006) mobilising natural and human resources for development (Boateng, Afranie \& Amoah, 2016), conflict management (Brempong, 2007; Acquah, 2006) among others.

The significance and prestige of the chieftaincy institution coupled with the functions chiefs performed came under threat with the advent of colonialism. An interplay of other currents of social change such as western education and Christianity, drastically constrained chiefs in the performance of their functions (Brempong, 2007; Rathbone, 2000). The powers and functions of chiefs were usurped by the colonial administration and actors of some state institutions like the local government system. The inclusion of chiefs in the indirect and direct rule system in the British colony also exacerbated the predicaments of chiefs. Some chiefs regarded their membership on Native Courts as an opportunity for amassing wealth, thus opening the floodgates for bribery and corruption to tarnish the once highly touted sacrosanct institution (Rathbone, 2000). The new African political elites and the masses during the upsurge of nationalist movements tagged chiefs 
as collaborators of the colonial regime. Chieftaincy was considered a huge obstacle that retrogressed the independence agenda being championed by the nationalists.

The African political nationalist agitators questioned the significance of the chieftaincy institution. Some regarded chieftaincy as an anachronistic institution within the context of the evolution the society was experiencing (Abotchie, Awedoba \& Odotei, 2006; Rathbone, 2000). Those who held such an orientation even predicted the death of the institution. Opinions were thus divided prior to independence, on the significance of chieftaincy and the expected roles chiefs were to perform in the new nation to be established. In more recent times, the behavior of some chiefs and events within the institution such as the incidents of chieftaincy and land related disputes has resurrected the debate on the significance of the chieftaincy institution in the era of modernity.

Critics have not only labelled the institution as a cankerworm but advanced the claim that globally, entrenched democratic governance has led to the relegation of the chieftaincy institution (Adu, 2008). Officials of the central government have been cautioned to desist from supporting this undemocratic institution within an era where efficient institutions have been established to perform the functions that hitherto chiefs performed. Chieftaincy has stood the hostile sails of modernity despite calls for its abolishment. Ghanaians continue to attach deep sentiments to and are fascinated about chieftaincy and revere greatly the men and women who occupy the stools and skins of their ancestors (Rathbone, 200o). The paper specifically seeks to answer two fundamental questions: Is chieftaincy anachronistic? And, how relevant is chieftaincy in Ghana's democratic dispensation? In line with the above, the rest of the paper is structured as follows: literature review section, section on methodology, findings and discussion section and conclusions and recommendation section.

\section{A REVIEW OF THE CHIEFTAINCY INSTITUTION IN GHANA}

Traditional political systems in Ghana are categorised into two-centralised and non-centralised. A centralised political system is characterised by a centralised authority that runs administrative machinery and judicial institutions or simply a government made up of a few people within the populace tasked with the steering of the daily affairs of the society (Fortes \& Evans-Prichard, 1961). Prior to colonialism, the Ashanti, Yoruba and Zulu societies of Ghana, Nigeria and South Africa respectively, had 'highly developed centralised political organisations with differentiated hierarchies of office holders' (Busia, 1962, p.69). Non-centralised 
political structures on the other hand lack the features of centralised structures and are practised by the Nuer (Sudan), Tallensi (Ghana) among others. However, based on the country's colonial heritage, a mixed government characterises the political landscape of the country in which traditional political structures co-exist with modern governmental structures (Englebert, 2003; Sklar, 2003).

In Ghana, Parliament is prohibited from enacting laws that confers on an individual the right to accord or withdraw recognition to or from a chief for any purpose or derogate the honor and dignity of the chieftaincy institution (Republic of Ghana, 1992). National and Regional Houses of Chiefs have been established to enable chiefs contribute to national development. Though chiefs are debarred from engaging in partisan politics, qualified paramount chiefs are eligible for appointment onto national commissions and authorities such as Regional Prison Committees, Regional Police Committees, and the Council of State (Republic of Ghana, 1992). The functions of chiefs are categorised into statutory and non-statutory functions (Brempong, 2007). Statutory functions denote functions that have been enshrined in the Constitution for chiefs to perform such as advising officials of government on matters that border on chieftaincy, and adjudicating chieftaincy disputes (Republic of Ghana, 1992). Non-statutory functions are those carried from the past but modified with the passage of time namely dispute settlement, performance of periodic sacrifices, organisation of festivals, acting as agents of development (Brempong, 2007).

Arhin (1985) in an analysis of traditional rule in Ghana, enumerated the financial sources available to traditional rulers, and the relationship between central government actors and chiefs who are vital stakeholders in community development. Both sociological and political approaches were employed to explore how chieftaincy persisted during pre-colonial and post-colonial eras. As the demands of chiefs increased with respect to territorial expansion, chiefs had to generate revenue through diverse sources to facilitate the performance of their functions (Arhin, 1985).

Critics of the chieftaincy institution have raised a number of issues to back their claim of the irrelevance of the institution in the current political dispensation. The advent of colonial rule and the inheritance of newly established political structures transformed the chieftaincy institution. For instance, though the colonial administration co-opted chiefs into the administration of the colony, the British government relieved chiefs of some of their duties (Brempong, 2007; Rathbone, 2000). The powers taken from the chiefs by the colonial administration 
included 'the power to make war, the power to make rules for the maintenance of law and order, and the power to take measures to promote the economic and social welfare of the people' (Arhin, 1985, p. 89). The erosion of the economic powers of chiefs, has led to some of them engaging in corruption such as allegedly soliciting gifts from potential candidates to vacant stools. Corruption, which refers to 'the practice associated with the giving and receiving of bribes' (Nukunya, 2016, p.237) is manifested during enstoolment, destoolment, dispute settlement in which disputants try to twist justice thereby tarnishing the integrity and credibility of chiefs (Boaten, 1994).

Boafo-Arthur (2006) elucidated some challenges that beset chieftaincy. The origins of the challenges in the institution commenced with the arrival of the European merchants. These merchants, initially preoccupied with trade and the propagation of the Gospel, succeeded in establishing 'political control or governance over the people on the coastal belt of Ghana' (Boafo-Arthur, 2006, p.146) and gradually extended their control to other parts of the country. Though the colonial expansion met some local resistance, the British managed to establish their courts which were considered paramount to traditional courts in terms of powers and judicial jurisdiction. The establishment of formal courts reduced the judicial powers of chiefs and limited the revenue that chiefs generated through judicial proceedings.

From the post-colonial era, the greatest challenge chiefs faced was attempts by the new political intelligentsia to subjugate chiefs. In addition, the institution itself was bedeviled with challenges such as succession disputes, inter-ethnic and intra-family disputes, the existence of dehumanising and obnoxious cultural practices and others (Brempong, 2007; Boafo-Arthur, 2006). The impact of these challenges on national development cannot be overemphased. Not only have the meager national resources been devoted to curbing chieftaincy disputes across the country, but it has also affected the collaboration between chiefs and some agents of development like private investors and local government officials committed to poverty alleviation.

Despite the above challenges chieftaincy is relevant in governance and economic development. Chiefs through festivals generate revenue for developmental purposes. Revenue is generated through sponsorship deals from cooperate organisations, fund raising on the climax of the celebrations of festivals and pledges by the central government. Funds mobilised are channeled into projects aimed at poverty alleviation. Prior to the organisation of festivals, chiefs in collaboration with members of the planning committee, set developmental objectives they hope to provide at the end of the occasion. Thus, the fundamental aim of festivals is 
to solicit funds from local and international investors for the improvement of traditional areas (Brobbey, 2008).

Chiefs and their Traditional Councils are strategically placed to assist the central government in charting a sustainable developmental path. In their quest to enhance socio-economic growth, chiefs have amalgamated diverse ethnic groups by establishing peace and stability among disputants and also between their institution and the central government. The long standing relationship with the central government for instance has compromised their neutrality (BoafoArthur, 2006; Boaten, 1994). Chiefs who declined to be political stooges especially under Kwame Nkrumah's government were marginalised and ridiculed and their communities deprived of social amenities (Boafo-Arthur, 2006; Rathbone, 2000). Despite the challenges that confront modern chiefs, some have led by example by becoming partners in community development.

Akrong (2006) examined traditional leadership and the place of religion in socio-economic development. A chief's authority is 'based on the idea that the leader mediates between the community and the divine and indeed leadership is legitimised by its relationship with the spiritual realm' (Akrong, 2006, p.194). Successfully completing all rituals required for enstoolment, accords the chief the right to exercise both moral and ritual authority over his people. As the intermediary between the living and the ancestors (Nukunya, 2016) the chief has to observe taboos meant not to jeopardise his reign, but rather harmonise his relationship with his forebears.

\section{METHODOLOGY}

\section{Study design}

The paper used desk review approach, relying on existing secondary literature on the subject matter (Johnston, 2014; Hakim, 1982). It is a flexible approach which provides options for researchers with limited time and resources (Johnston, 2014).

\section{Search Strategy}

Secondary data from the Balme Library of the University of Ghana and also journal articles from Google Scholar and Google were reviewed. The two online databases were used because they are broad-based data that cut across diverse disciplines. The collation of information from the above sources facilitated the exploration of the research questions. Taking cognisance of the research questions, the following 
search terms were utilised in the search - "chieftaincy and development" OR "the role of chiefs" OR "challenges of chiefs in the modern era" OR "the relevance of chiefs or the chieftaincy institution".

The searches were confined to books and papers written in English language. The review was conducted between July 7, 2019 and October 25, 2019. The review focused on qualitative, mixed methods and quantitative studies on chieftaincy conducted in Ghana up to 2019. Two of the 43 publications used quantitative methods while 5 and 36 used mixed methods and qualitative methods respectively.

\section{Selection of Studies}

The search in the library yielded about one hundred and twenty (120) materials. Additionally, Google Scholar and Google yielded 730 and 891 materials respectively. These materials in the three sources included books, policy documents, journal articles, research reports and pamphlets. After excluding pamphlets, the search in Google yielded 234 journal articles, books and research reports, Google Scholar yielded 321 academic materials, library sources also yielded 52 materials. The above materials were scrutinised as part of the process to ensure that relevant materials were only included in the study. As such, materials that did not focus on social change and chieftaincy, the role of chiefs in Ghana and whether chieftaincy is anachronistic were excluded. Materials that met the inclusion criteria were selected. Finally, a shortlist of sixty-three studies underwent a second review before a final list of fifty-one (51) were selected for critical review.

\section{Data Extraction and Analysis}

Data extraction from qualitative studies was conducted by synthesising similar themes that touched on the role of chiefs and whether the chieftaincy institution was anachronistic or not. Descriptions of findings in the results and discussion sections of the materials reviewed served as potential data. Similar exercise was conducted for the quantitative and mixed method studies. Information for this review was obtained legally and the sources duly acknowledged.

\section{RESULTS AND DISCUSSION}

In this section, chieftaincy and social change and the contributions of chieftaincy to development are discussed. 


\section{Social Change and the Anachronistic Labelling of the Chieftaincy Institution}

Social change is ubiquitous, transforming society as it evolves with the passage of time. Social change is the totality of significant changes in a society (Nukunya, 2016). It also connotes the significant alteration in the social structure, which may originate endogenously or exogenously in any institutional area, bringing about changes in other parts of society. Changes in any of the structures of society must be significant enough to alter other parts of the social structure. For an extrapolation of the trends in change, a point of commencement and termination within which change proceeds must be established. In Africa, the year 1900 is considered as the yardstick for analysing social change (Nukunya, 2016).

Of the numerous factors of social change, colonialism had significant impact on Ghana's social structure (Nukunya, 2016). The establishment of colonial rule and the rise of nationalistic movements called for the introduction of legislations, which brought some changes into the colony. By virtue of the fact that colonial rule witnessed the establishment of government over existing traditional political institutions, chiefs lost a great part of their autonomy (Nukunya, 2016). During the colonial era, chiefs lost their power by virtue of their inclusion in the colonial administration where they played subservient roles to the colonial officials. In the immediate post-colonial periods, the rationale for relegating chiefs to the background was the perception that chiefs were collaborators of the colonial regime (Brempong, 2007; Rathbone, 2000). This orientation and the fact that government officials considered chiefs as their competitors and the undemocratic nature of the institution, trickled into the Fourth Republic. The PNDC regime that was mandated to draft a constitution for the nation, considered the integration of chiefs into structures of governance as an affront to the ethos of democracy (Ayee, 2007).

Historically, chiefs administered their subjects with the aid of their council of elders and the backing of a military force. The military force was used to wage expansionist campaigns and to curtail both internal and external aggressors. However, in both the colonial and post-colonial periods, chiefs are debarred from maintaining any form of military force. The task of defending the citizens from aggressors during the colonial era was placed under the Governor of the colony while in the postcolonial era, this task is placed under the President of the Republic. The President may exercise this function directly or any of his/her subordinates designated to do so by law. The President presides over meetings of the National Security Council, 
tasked to consider and take appropriate measures to safeguard the internal and external security of the country (Republic of Ghana, 1992).

The economic functions of chiefs were transformed by the factors of social change. Historically, economic activities and local governance revolved around chiefs (Ahwoi, 2010; Rathbone, 2000). Chiefs and their elders were tasked to strategise for the community especially for the implementation of projects and also to propose economic plans for community members to undertake. As custodians of communal property resources (CPRs), chiefs in Ghana are to sustainably manage them on behalf of the ancestors, the living and generations yet unborn (Alhassan, 2006; Seini, 2006). Their significance in the economic pursuit of their subjects was interwoven with their religio-political functions. Chiefs were mandated to at the commencement of the cultivation period and during traditional festive occasions, offer sacrifices and pray the ancestors for fertility, good harvest and protection. In return, chiefs periodically received tributes and portions of the produce generated on lands and other communal properties within their jurisdiction. In the past, centralised states generated revenue from two sources; taxes and levies for specified and extraordinary purposes and labour services on the chiefs' dwellings (Brempong, 2007). For communities that major trade routes passed through, traditional scouts under the command of chiefs exacted agreed custom fees. Revenue and items mobilised were channeled into state coffers and used to develop the community or used by chiefs and their functionaries.

However, the customary taxes and levies chiefs generated were regulated by the colonial administration (Brempong, 2007). Economic liberalism due to the introduction of cash crops deprived chiefs of revenue. In contemporary Ghana, economic planning has been transferred from chiefs to the National Development Planning Commission (NDPC). The Commission is mandated among other things, to ensure sustainable utilisation of the natural and physical environment and even development of all districts in the country (Republic of Ghana, 1992).

At the local level, the District Assemblies and other local government structures plan for the various communities under their jurisdiction. These strategic plans are sent to the NDPC through the respective Regional Coordinating Councils (RCCs) for consideration and onward submission to the central government. The plans consist of the various developmental agenda and timelines for implementation. The tax collection functions of chiefs have been transferred to the District Assemblies to generate revenue for developmental purposes. 
The loss of economic powers of chiefs derailed their efforts in the fight against poverty in rural areas. By virtue of the fact that chiefs are not permitted to collect taxes, those without economically viable resources like gold, timber, diamonds and others in their communities, are unable to undertake capital intensive projects such as the construction of social amenities. The inability of chiefs to combat poverty has placed huge demands on the central government and the District Assemblies in their quest to provide social amenities for their people. This has even been exacerbated by the erosion of the communal spirit chiefs once capitalised for social mobilisation.

As custodians of communal resources (Alhassan, 2006) chiefs were only permitted to sell lands with the approval from their traditional council. The researchers identified a reduction in the custodial functions of chiefs regarding communal resources resulting in multiple sale of land, land litigations and illegal mining. In northern and middle sectors of Ghana, chiefs preferred to transfer fertile cultivatable lands to rich pastoralists who were willing to make substantial monetary payments (Amanor \& Ubink, 2008; Tonah, 2006; 2002) resulting in intense competition between indigenes and migrants.

In peri-urban areas in Kumasi, chiefs have dispossessed farmers of their lands and given to rich urban dwellers willing to pay for real estate development by redefining customary land tenure ownership (Ubink, 2008). Some chiefs have engaged in multiple sale of lands to private investors. In communities with chieftaincy dispute, rivalry factions are alleged to have sold lands without recourse to laid down practices. Some chiefs and their rival factions together with some private developers have contracted the services of vigilante groups called land guards, to protect their properties. These land guards have terrorised people and destroyed life and property around peri-urban areas. This has resulted in numerous land disputes which involve expensive, cumbersome and time consuming adjudication processes. This situation could have been avoided if the country was committed to an efficient land registration regime, timely adjudication of land cases, effective policing in arresting land guards and creation of employment opportunities (Jafaru, 2017). The inability of the state to exact accountability from chiefs has resulted in the lack of accountability regarding customary land management (Ubink, 2008) and financial transactions on CPRs.

The upsurge of illegal mining and its resultant destruction of the environment has occurred due to two fundamental reasons. First is government's inefficiency in implementing environmental regulations. Some individuals have also placed 
the blame squarely at the doorsteps of chiefs. Some chiefs have sold lands to illegal miners who have exploited the environment instead of ensuring their sustainability. Illegal mining has led to the destruction of numerous water bodies, farm lands and economic trees such as timber and cocoa. Young ladies in mining communities have established brothels to 'service' miners and other patrons (Ngnenbe, 2019). The inability of chiefs to protect environmental resources has tarnished the reputation of the chieftaincy institution leading critics to question its relevance in contemporary era.

Chieftaincy disputes, conservatism due to traditions and customs, and financial constrains have led critics to downplay the institution in contemporary Ghana. Disputes have bedeviled the chieftaincy institution (Ahiave, 2013). Places such as Cape Coast, Winneba, Bawku among others (Yahaya, 2016; Brukum, 2006; BoafoArthur, 2006) have encountered longstanding chieftaincy conflicts. Though some have alluded that disputes within the chieftaincy institution is an attestation of the prestige attached to the institution (Abotchie et al., 2006), such disputes have negative impacts on national development. The slow socio-economic growth in Winneba is primarily attributed to the long-drawn-out conflict between the Ghartey and Ayirebi-Acquah gates (Yahaya, 2016; Boafo-Arthur, 2006). The loss of human life and other resources due to chieftaincy conflicts, could in the long term affect the growth and development of the nation.

Traditionalism or conservatism was one of the challenges besetting the chieftaincy institution and thereby motivating critics to question the relevance of the institution in contemporary Ghana. Despite the currents of social change affecting chieftaincy, chiefs have been able to retain some aspects of their traditions and customs. The existence of some cultural practices are not only against human rights of the people but are also detrimental to socio-economic development. Though the framers of the 1992 Constitution, tasked the National House of Chiefs to 'undertake an evaluation of traditional customs and usages with a view to eliminating those customs and usages that are outmoded and socially harmful' (Republic of Ghana, 1992, p.165), some still persist. Cultural practices such as widowhood rites, female genital mutilation (FGM) and ritual servitude (Trokosi) (Nukunya, 2016; AkpabliHonu, 2014; Sarpong, 2012) infringe on the human rights of women.

The criteria for nominating and selecting chiefs have been regarded as undemocratic. Though in a few instances queen mothers have assumed the position of chiefs, males have predominately been enstooled and enskinned as chiefs. Unlike in a democratic dispensation where everyone has the right to contest an election, 
the queenmother selects the prospective chief and presents him to the kingmakers for consideration. To be eligible to become a chief, one has to be able to trace ancestry to the original founders of the community (royal family) and must be persons without any physical defects. This practice has been regarded as discriminatory and an infringement on the human rights of the physically challenged members of the royal family (Obimpeh, 2013) although Article 29 (4) of the 1992 Constitution prohibits subjecting people with disability to discriminatory, abusive and degrading nature (Republic of Ghana, 1992). This restrictive recruitment procedure is an affront to the rule of law which emphasises mass political participation in decisionmaking, right to contest election, among others.

Thus, the loss of the powers and functions of chiefs due to social change, traditionalism that characterises the institution, chieftaincy conflicts due to succession rights, multiple land sales and the upsurge of illegal mining have tarnished the reputation of the chieftaincy institution. Corruption, perception of the undemocratic inclination of the institution are some of the arsenals that arm these critics who postulate for the abolition of the institution.

\section{THE INSTRUMENTALITY OF THE CHIEFTAINCY INSTITUTION TO DEVELOPMENT}

Though chieftaincy is engulfed in a web of challenges, the contributions of the institution to national development cannot be overlooked. This section discusses the contribution of chiefs to national development and argues for the modification of the institution to meet the exigencies of the changing Ghanaian society.

\section{Governance and Participation in Decision Making}

Governance connotes the capacity of a government to make, enforce and deliver social services to its citizens. Governance primarily deals with the manner in which institutions carry out their assigned functions. It relates to the manner in which power is exercised in pursuant to the management of the economic and non-economic resources of a community. As leaders, chiefs continue to perform multiplicity of functions synonymous with modern governmental systems (Frempong, 2006). Chiefs continue to govern and provide leadership to their people. In rural sectors especially, the absence of state institutions means that chiefs provide an invaluable avenue for directing and guiding community members in the pursuit of their daily enterprises. 
For the purpose of governance, the Akans are politically categorised at three fundamental levels namely the village, division (Omansin) and state (Oman). The division and the state have capitals which are the seats of the political heads (Nukunya, 2016). Each of the three political levels has its respective governing council made up of representatives from recognised political offices and coopted members. The concept of political representation is widely entrenched as adults were represented in the governing councils (Brempong, 2007).

Several mechanisms were instituted to check the governmental powers of chiefs within the Akan political system. Apart from misfortunes characterising the regime of an autocratic chief, his council of elders serve as a check on his powers. A chief is bound by tradition, to periodically consult his traditional council for advice. In addition, the queenmother advices the chief on issues that border on traditions and customs. These measures are meant to check the arbitrary use of political power.

Despite the establishment of a modern government, chiefs and their councils acting as a cabinet, continue to have enormous influence and control over the lives of their subjects. Chiefs continue to enact customary laws to regulate the activities of their subjects and to also mange environmental resources (Agbenorku, 2010; Alhassan, 2006). Recently, chiefs and local government actors collaborate in administering communities under their jurisdictions. This collaboration in governance and other related activities is indicative of the existence of a mixed government that characterises the political landscape of Africa (Sklar, 2003; Englebert, 2003; Odotei, 2003).

\section{Conflict Resolution and Unification of heterogeneous Community}

Conflicts are prevalent in every social organisation. Attempts to settle disputes in post-colonial Ghana have heavily tilted towards the adoption of approaches based on British jurisprudence (Acquah, 2006; Fred-Mensah, 2005). This notwithstanding, traditional courts headed by chiefs, are resorted to by disputants. Factors such as delays through case adjournment, administrative and legal procedural challenges and the cost of seeking redress in formal courts, legal terminologies used and others account for the patronage of traditional courts (Kuusaana, Kidido, Appiah \& Mireku, 2013; Crook, 2005). Traditional courts are regarded by most rural dwellers as less intimidating characterised by the incorporation of informal processes that indigenes are accustomed to (Kuusaana et al., 2013). As such, traditional courts are able to accommodate people of various backgrounds. 
Although the judicial functions of chiefs have been transformed with the passage of time, chiefs continue to be instrumental in conflict management and resolution. In order to build a harmonious community, chiefs are tasked to identify situations in their territories which have the propensity to bring about conflict or favour the escalation of conflict. In event of conflicts, chiefs try to manage them by mitigating the repercussions of the violence and developing trust among disputing groups.

The palaces of chiefs in Ghana serve as courts. As a result, three hierarchical levels of traditional courts namely: courts of the sub-chiefs (the lower court), divisional chiefs (middle court) and the court of the paramount chief (highest court) typify traditional political system (Acquah, 2006). Disputants dissatisfied with the ruling of a lower court, within an Akan establishment, may invoke the oath of a superior chief (Nukunya, 2016) resulting in migrating the case to the superior court. Cases settled by traditional courts include theft, marital disputes, land and boundary litigations, chieftaincy disputes, among others (Nukunya, 2016; Kuusaana et al., 2013; Abotchie et al., 2006; Crook, 2005). Thus, chiefs serve as disturbance handlers (Abdulai, 2006), taking corrective measures in conflict situations to restore law and order.

As a healing process, the fundamental objective of conflict resolution is to restore broken relationships and social justice (Brock-Utne, 2001). Failure on the part of chiefs to resolve conflicts peacefully may incur the displeasure of the gods and ancestors. The process towards reconciliation involves some symbolic gestures and associated rituals. Prior to the commencement of a case, disputants presented gifts that include animals such as chickens, goats, sheep and locally manufactured gin to the court. These items were offered to the ancestors by the chief or an official of the court.

In trying to resolve the chieftaincy crises in Dagbon which claimed the life of the Ya Na Yakubu Andani II (the king of Dagbon) and forty other individuals (Tsikata \& Seini, 2004), for instance, a committee composed of three eminent chiefs under the chairmanship of Otumfuo Osei Tutu II, the Asantehene was constituted in 2003. Other members of the committee included the overlord of Mamprugu, Nayiri Naa Bohagu Abdulai Mahami Sheriga and the Yagbonwura, Tuntumba Boresa I. Prior to the formation of the Otumfuo Committee, strategies such as military and police intervention through the imposition of curfews, establishment of a Commission of Inquiry to investigate and find peaceful resolution of the conflict (Issifu, 2015; Tonah, 2012) were employed to manage the dispute. The three eminent chiefs were 
instrumental in settling the dispute which was preceded by the enskinment of a new king and organisation of the final funeral rites for the two late overlords.

Upon the assumption of power, the current Asantehene mandated his subordinates to withdraw all chieftaincy cases from modern courts for arbitration at his palace (Boafo-Arthur, 2006; Owusu-Sarpong, 2003). Chiefs have also resolved conflict involving government and trade unions and students and government (Abotchie et al., 2006) over benefits and working conditions. Also, the queenmother's courts are used to settle disputes among married couples and other members of the society. Through conflict resolution, chiefs are able to unite diverse ethnic groups in Ghana.

\section{Economic Empowerment}

Chiefs traditionally are the custodians of all economic assets under their territories. Despite the reduction of their economic powers, issues of socio-economic development continue to revolve around chiefs at the local level. Currently, chiefs are selected based on the amount of assumed social capital and networks they have. The belief is that a prospective candidate with enormous social capital can utilise it in the sphere of community development. Based on this fundamental orientation, kingmakers now are inclined towards selecting educated and professionals with a considerable wealth of experience in project formulation and funding, health and advocacy and education.

Chiefs have enstooled or enskinned non-hereditary actors as development chiefs (Nkosuohene) (Akrong, 2006). The Nkosuo stool was instituted by the late Asantehene Otumfuo Opoku Ware II, on the occasion of the Golden Jubilee of the Restoration of the Asante Union in 1985 (Brempong, 2007; Akrong, 2006). The late King considered this new office as an opportunity for beneficiaries to use their professional networks to bring the needed development into their communities (Brobbey, 2008; Steegstra, 2006). Though these title holders lack political power and mostly are without ancestral connections to the founders of the community, their wealth and influence is expected to bring the necessary development at the local level (Steegstra, 2006).

Though the stool was initially instituted for Ghanaians, some foreigners have been rewarded with the nkosuo title in recognition for their contributions to development (Brempong, 2007; Akrong, 2006; Boafo-Arthur, 2006; Steegstra, 2006). Occupants mobilise funds from diverse sources and periodically report progress on projects to donors as a way of ensuring accountability. Despite the concept originating from Asante, other traditional areas in Ghana have instituted 
this laudable initiative (Brempong, 2007). The success of a chief is measured by the quantum of developmental initiatives he has implemented during his tenure. Chiefs have travelled far and near, visiting companies, donor agencies and other Non-Governmental Organisations (NGOs) to solicit funds for community initiated projects. Through these travels and other platforms like festivals, chiefs try to woo investors into their traditional areas.

Traditional rulers such as Amoatia Ofori Panyin, Togbe Afede XIV, Nana Otuo Siriboe II and Otumfuo Osei Tutu II (Boateng, 2010; Boafo-Arthur, 2006) have implemented diverse developmental projects in their traditional areas. As part of empowering their subjects, these paramount chiefs have established rural banks, oil palm refineries, block and brick industries, and a hydro power and airline companies in the case of Togbe Afede XIV (Bewiadzi, 2013; Boateng, 2010). These establishments have provided jobs to numerous people in the country.

\section{Representational and Diplomatic Roles}

Chiefs do not only administer their people but represent them in their interactions with external organisations and at social gatherings such as festivals, funerals and durbars (Abdulai, 2006). During such encounters, chiefs act in a decorous manner necessary to project and protect the image of their ancestors and people. As political heads, chiefs receive visitors on behalf of their people. Government officials, agents of donor community, and officials of NGOs who visit any community, call on the chief to seek their approval before embarking on any activity. During electioneering years, political party leadership constantly lobby chiefs to enhance their electioneering chances at the local level.

During encounters with politicians and donors agencies, chiefs project the investment potentials of their communities. As leaders, chiefs enter into agreements or negotiations on behalf of their people. Another latent effect of the representational role of chiefs pertains to their ability to showcase the traditions and culture of their people to the outside world. Aspects of their culture are depicted through the regalia and other paraphernalia that chiefs adorn themselves with. These regalia provide historical accounts about the trade contacts, migrations, wars, artistic creativity and aesthetic values of their people (Labi, 2006). These cultural symbols are proudly displayed during festivals which continue to attract diverse people. 


\section{Education and Advocacy}

Provision of quality education for the country's citizens is a fundamental prerequisite for socio-economic development. Quality education must equip people to fully participate in decision - making. The strategic objective therefore, is to improve on the quality of teaching and provide the necessary learning materials for both teachers and students in order for education to be able to transform society.

Chiefs have now embraced the fight against poverty, ignorance, social exclusion and taking strides to enhance the quality of education in Ghana. Chiefs have instituted scholarship schemes, provided educational infrastructure such as teachers' bungalows, classroom blocks, computers, textbooks to both teachers and students at all levels of the educational system. Togbe Afede XIV since his installation has reconstructed schools, established the Asogli Education Fund, donated books worth over 480 million cedis to schools under his jurisdiction (Bewiadzi, 2013). The Otumfuo Education Fund on the other hand has offered scholarship assistance to millions of students across the country.

The mobilisation of their subjects to engage in self-help educational activities is one paramount objective of chiefs. Chiefs are better positioned in this regard considering the entrenched communal spirit in the rural areas. Members of the community believe that contributions towards human resource development of the community will in the long run benefit the collectivity. It is expected that beneficiaries of the educational schemes upon completion of their education, will return similar gestures to other members of the community. This mutual benefit is what motivates members of the community to contribute towards such scholarship schemes. Consequent on the above, the chiefs in the Asogli State prior to the establishment of the Education Fund, donated about $10 \%$ of land proceeds as seed capital while prominent citizens of the traditional area also made financial contributions towards the materialization of this initiative (Bewiadzi, 2013).

Aside the institutionalisation of the scholarship schemes, chiefs have been leaders by example, by educating their own children (Seini, 2006). This has given them the moral currency to be educational advocates in the rural areas where the standards of education and access to education are a huge challenge. By virtue of the currency attached to the chieftaincy institution, chiefs have become better advocates, interpreting and disseminating governmental policies (Brobbey, 2008; Abotchie, 2006) in rural sector characterised by weak governmental institutions. Chiefs have become advocates in education, on climate change, environmental sustainability and on healthy living. State institutions such as the Environmental Protection 
Agency (EPA), the Ghana AIDS Commission and Non-Governmental Organisations (NGOs) have coopted some prominent paramount chiefs to advance their objectives.

\section{CONCLUSIONS AND RECOMMENDATION}

The paper sought to investigate whether the chieftaincy institution is anachronistic and has totally lost its relevance in the current democratic dispensation. The anachronistic label of chieftaincy was anchored on the undemocratic inclination, the erosion of the powers and functions of chiefs by currents of social change, chieftaincy and land disputes, the existence of some obnoxious traditions and customs among others. Perhaps, it is important to note that most of these issues raised are not the preserve of chiefs alone. Officials in democratic institutions and other state institutions have also been accused of engaging in multiple sale of land, illegal mining and corruption. Currently, the country is struggling with political vigilantism that has characterised elections at both national and party levels. There have been cases of violence between members of different political parties. In view of the above challenges, should these also call for abolishing the modern political system or we should work to improve it?

Notwithstanding the above challenges, some chiefs have collaborated with the central government and other donor agencies to initiate and implement developmental projects in their traditional areas. The essence is to empower their subjects so that they will be able to cater for their family members and other dependents. In this endeavor, chiefs contribute to development through conflict resolution, promotion of education and advocacy in rural areas, performing representational and diplomatic roles just to mention but a few.

Though the perception that chieftaincy is anachronistic still persists, the resilience of the institution, having stood the hostile strides of social change is an illustration that the institution has critical roles to play in contemporary Ghana. There is the need therefore, for chiefs to be mindful of their position and act appropriately and rid themselves of all negative tags associated with the institution. Future studies should also consider how chiefs can respond appropriately to the challenges that beset the institution. 


\section{REFERENCES}

Abdulai, A. I. (2006). The Ghanaian Chief as a manager: Between tradition and modernity. In I. K. Odotei \& A. K. Awedoba (Eds.), Chieftaincy in Ghana: Culture, Governance and Development (pp. 565-585). Sub-Saharan Publishers. ISBN 9789988-550-74-2.

Abotchie, C. (2006). Has the position of the Chief become anachronistic in contemporary Ghanaian politics? In I. K. Odotei \& A. K. Awedoba (Eds.), Chieftaincy in Ghana: Culture, Governance and Development (pp.169-191). SubSaharan Publishers. ISBN 978-9988-550-74-2.

Abotchie, C., Awedoba, A. K. \& Odotei, I. K. (2006). Perceptions on Chieftaincy. In I.K. Odotei \& A.K. Awedoba (Eds.), Chieftaincy in Ghana: Culture, Governance and Development (pp.103-143). Sub-Saharan Publishers. ISBN 978-9988-550-74-2.

Acquah, G. K. (2006). The Judicial role of the chief in Democratic Governance. In I. K. Odotei \& A. K. Awedoba (Eds.), Chieftaincy in Ghana: Culture, Governance and Development (pp.65-79). Sub-Saharan Publishers. ISBN 978-9988-550-74-2.

Adu, A.N. (2008). The Inevitable Demise of Chieftaincy. Retrieved from https://www. ghanaweb.com/GhanaHomePage/features/The-Inevitable-Demise-ofChieftaincy-146514

Agbenorku, J. (2010). Partnership modalities between Metropolitan, Municipal, District Assemblies and Traditional Authorities. Journal of Local Government Studies, 2(1), 1-21. ISBN: 2026-5840.

Ahiave, E. C. (2013). Conflict and conflict resolution in Ghana: The case of Dagbon conflict. (Unpublished MPhil thesis), Department of Political Science, University of Ghana, Legon.

Ahwoi, K. (2010). Local Government and Decentralization in Ghana. Unimax Macmillan Ltd.

Akpabli-Honu, K. (2014). Female Bondage in Ghana. A Study of Troxovi System Among the Ewes of Ghana. Woeli Publishing Services.

Akrong, A. (2006). Religion and Traditional leadership in Ghana. In I. K. Odotei \& A. K. Awedoba (Eds.), Chieftaincy in Ghana: Culture, Governance and Development (pp. 193-212). Sub-Saharan Publishers. ISBN 978-9988-550-74-2.

Alhassan, O. (2006). Traditional authorities and sustainable Development: Chiefs and Resources management in Ghana. In I. K. Odotei \& A. K. Awedoba (Eds.), Chieftaincy in Ghana: Culture, Governance and Development (pp. 527-546). SubSaharan Publishers. ISBN 978-9988-550-74-2. 
Amanor, K. S. \& Ubink, J. M. (2008). Contesting Land and Custom in Ghana State, Chief and the Citizen. Leiden University Press.

Arhin, K. (1985). Traditional Rule in Ghana: Past and Present. Sedeco Publishing Limited.

Ayee, J. R. A (2007). Traditional Leadership and Local Governance in Africa: The Ghanaian Experience, presented at the Fourth National Annual Local Government Conference, Southern Sun - Elangeni, Durban, July 2007.

Bewiadzi, S. (2013). Agbogbomefia Togbe Afede XIV and The Politics of Development in The Ho-Asogli State. (Unpublished MPhil thesis), Institute of African Studies, University of Ghana, Legon.

Boafo-Arthur, K. (2006). Chieftaincy in Ghana: Challenges and prospects in the $21^{\text {st }}$ century. In I. K. Odotei \& A. K. Awedoba (Eds.), Chieftaincy in Ghana: Culture, Governance and Development (pp. 145-168). Sub-Saharan Publishers. ISBN 9789988-550-74-2

Boaten, B. A. (1994). Chieftaincy in Ghana - An Overview. Institute of African Studies, University of Ghana. (Mimeo).

Boateng, K., Afranie, S., \& Amoah S. K. (2016). Social Mobilisation in the Midst of Social Change: The Case of Traditional Authorities in Ghana. Journal of Educational and Social Research, 6(2), 103-112. https;//doi:10.5901/jesr.2016. v6n2p103.

Boateng, K. (2010). Chiefs as Agents ofDevelopment: Astudy of Chieftaincy and Community Development in the Asante Juaben Traditional Area. (Unpublished MPhil thesis), Department of Sociology, University of Ghana, Legon.

Brempong, A. (2007). Transformation in Traditional Rule in Ghana, 1951-1996. Legon: Institute of African Studies. ISBN 9988-8300-7-6.

Brobbey, S. A. (2008). The Law of Chieftaincy in Ghana: Incorporating Customary Arbitration, Contempt of Court, Judicial Reviews. Advanced Legal Publication.

Brock-Utne, B. (2001, February). Indigenous Conflict Resolution in Africa. Paper presented at Indigenous Solutions to Conflicts Seminar, University of Oslo, Institute of Educational Research.

Brukum, N. J. K. (2006). Chieftaincy and Ethnic conflicts in Northern Ghana, 19802002. In I. K. Odotei \& A. K. Awedoba (Eds.), Chieftaincy in Ghana: Culture, Governance and Development (pp. 429-448). Sub-Saharan Publishers. ISBN 9789988-550-74-2.

Busia, K. A. (1962). The Challenge of Africa. Frederick A. Praeger Publishers. 
Crook, R. C. (2005). State courts and the regulation of land disputes in Ghana: the litigants' perspective. Institute of Development Studies, IDS Working Paper 241.

Englebert, P. (2003). Resurgent Indigenous Structures and the Reconfiguration of power in Africa. In O. Vaughan (Ed.) Indigenous Political structures and Governance in Africa (pp. 26-59). Oluseyi Press. ISBN 978-8059-06-6.

Fortes, E. \& Evans-Pritchard, E. (1961). African Political Systems. Oxford University Press.

Fred-Mensah, B. (2005). Nugormesese: An indigenous basis of social capital in a West African Community. 1 K Notes, No. 86, November. World Bank. Retrieved from http://www.worldbank.org/afr/ik/default.htm.

Frempong, A. K. D. (2006). Chieftaincy, Democracy and Human Rights in Pre-Colonial Africa: The Case of the Akan system in Ghana. In I. K. Odotei \& A. K. Awedoba (Eds.), Chieftaincy in Ghana: Culture, Governance and Development (pp. 379-393). Sub-Saharan Publishers. ISBN 978-9988-550-74-2.

Hakim, C. (1982). Secondary Analysis in Social Research: A Guide to Data Sources and Methods with Examples. Allen and Unwin.

Issifu, A. K. (2015). An Analysis of Conflicts in Ghana: The Case of Dagbon Chieftaincy. The Journal of Pan African Studies, 8(6), 28-44.

Jafaru, M. Y. (2017). Take measures to deal with land guards - MPs. Retrieved from https://www.graphic.com.gh/news/politics/take-measures-to-deal-withland-guards-mps.html.

Johnston, M. P. (2014). Secondary data analysis: A method of which the time has come. Quantitative and Qualitative Methods in Libraries, 3, 619-626.

Kuusaana, E. D., Kidido, J. K., Appiah, M. N. \& Mireku, K. O. (2013). Alternative Dispute Resolution by Chiefs and Tendamba: A Case Study of Kumasi and Wa Traditional Areas. The Ghana Surveyor, 5(1), 14-27.

Labi, K. A. (2006). Cross-Cultural Appropriation of regalia and royal art, and contemporary adaptations in Ghana. In I. K. Odotei \& A. K. Awedoba (Eds.), Chieftaincy in Ghana: Culture, Governance and Development (pp. 275-294). SubSaharan Publishers. ISBN 978-9988-550-74-2.

Ngnenbe, T. (2019). Aowin Omanhene decries resurgence of illegal mining. Retrieved from https://www.graphic.com.gh/news/general-news/aowin-omanhenedecries-resurgence-of-illegal-mining.html.

Nukunya, G. K. (2016). Tradition and Change in Ghana. Woeli Publishing Services. ISBN 978-9964-3-0293-2. 
Obimpeh, P. (2013). Chieftaincy Institution Has Outlived Its Usefulness - Kwesi Pratt. Retrieved from http://www.peacefmonline.com/pages/local/ news/201311/179640.php.

Odetei, I. (2003). Chieftaincy Politics in Ghana: Historical Dimensions. In O. Vaughan (Ed.), Indigenous Political structures and Governance in Africa (pp. 322-345). Oluseyi Press Ltd. ISBN 978-8059-06-6.

Owusu-Sarpong, C. (2003). Setting the Ghanaian Context of Rural Local Government: Traditional Authority Values. In D. I. Ray \& P. S. Reddy (Eds.), Grassroots Chiefs in Africa and the Afro-Caribbean Governance (pp. 31-67). University of Calgary Press. ISBN 978-1-55238-565-4.

Rathbone, R. (2000). Nkrumah and the Chiefs: The politics of Chieftaincy in Ghana 19516o. Ohio University Press. ISBN o-85255-770-1.

Republic of Ghana. (1992). Constitution of the Fourth Republic of Ghana. Assembly Press.

Sarpong, K. P. (2012). Odd Customs, Stereotypes and Prejudices. Accra: Sub-Saharan Publishers.

Seini, W. A. (2006). The Role of Traditional Authorities in Rural Development. In I. K. Odotei \& A. K. Awedoba (Eds.), Chieftaincy in Ghana: Culture, Governance and Development (pp. 547-564). Sub-Saharan Publishers. ISBN 978-9988-550-74-2.

Sklar, R. L. (2003). The premise of mixed government in African Political Studies. In O. Vaughan (Ed.), Indigenous Political structures and Governance in Africa (pp. 3-25). Oluseyi Press Ltd. ISBN 978-8059-06-6

Steegstra, M. (2006). White Chiefs and Queens in Ghana: Personification of 'Development'. In I. K. Odotei, \& A. K. Awedoba (Eds.), Chieftaincy in Ghana: Culture, Governance and Development, (pp.603-620). Sub-Saharan Publishers. ISBN 978-9988-550-74-2

Tonah, S. (2012). The politicisation of a chieftaincy conflict: The case of Dagbon, northern Ghana. Nordic Journal of African Studies, 21(1), 1-20.

Tonah, S. (2006). Migrationandfarmer-herder conflictsin Ghana's Voltabasin.Canadian Journal of African Studies 4O(1), 152-178. DOI: 10.1080/ooo83968.2006.10751339

Tonah, S. (2002). Fulani pastoralists, indigenous farmers and the contest for land in Northern Ghana. Afrika Spectrum 37(1), 43-60.

Tsikata, D., \& Seini, W. (2004). Identities, inequalities and conflicts in Ghana. CRISE working paper. CRISE. 
Ubink, J. M. (2008). In the Land of the Chiefs: Customary Law, Land Conflicts, and the Role of the State in Peri-urban Ghana. Leiden University Press.

Yahaya, A. B. (2016). Resolution of Chieftaincy Disputes and Reconciliation: A Case Study of the Effutu Traditional Area, Winneba. In S. Tonah \& A. S. Anamzoya (Eds.), Managing Chieftaincy and Ethnic Conflicts in Ghana (pp. 167-190). Woeli Publishing Services. ISBN 978-9988-2-3161-3. 